EDITORIAL

\title{
Death, Brain Death, and Organ Donation: A Work in Progress
}

\author{
Palepu BN Gopal
}

Indian Journal of Critical Care Medicine (2020): 10.5005/jp-journals-10071-23580

About a quarter of century ago, India joined the legion of countries that recognized brain death as a legal entity, thus paving the path for deceased donor organ donation and transplantation. This was done through the enactment of Transplantation of Human Organs Act (THOA) 1994, ${ }^{1}$ which eventually underwent several amendments. The awareness of brain death as an entity and promotion of organ donation were initially taken up by private and non-governmental organizations (NGOs) and institutions, such as the MOHAN (Multi-Organ Harvesting Aid Network) foundation. Eventually governmental organizations took lead of these programs and established a network of pyramidal organizations under National Organ Transplantation Programme (NOTP). ${ }^{2}$ The National Organ and Tissue Transplant Organization (NOTTO) was also established with an aim to oversee the entire program under the leadership of the Ministry of Health, Government of India. Despite these eventual changes, India is significantly lagging behind many, in both brain death declarations and organ donations. Whereas about 500,000 potential recipients are waiting to be transplanted each year in the country, only about 8,000 deceased donor transplantations are actually happening per year. It is imperative that the political, administrative and medical community analyze this glaring gap and evolve corrective measures, to promote this program toward saving more lives of recipients in waiting.

The definition of death was mentioned in the Registration of Births and Death Act, Government of India 1969. ${ }^{3}$ When THOA was passed in 1994, brain death is defined in that act only, and the Registration of Births and Death Act of Government of India has not been amended to include it in its ambit. In USA, these two entities have merged to evolve a unified definition of death, termed under Uniform Determination of Death Act (UDDA) 1981 USA as "an individual who has sustained either (i) irreversible cessation of respiratory and circulatory functions, or (ii) irreversible cessation of all functions of entire brain, including brainstem, is dead". ${ }^{4}$ Consequently, the duality and ambiguity of the mode of death remained in many an Indian mind, including healthcare workers. It took a long time to include the teaching of brain death in medical curricula as well, and this led to suboptimal level of awareness of this fundamental change in our law. To this day, unfortunately, for these and some other reasons, brain death is viewed by many as an implement necessary only preceding deceased organ donation. Apart from the confusion about a uniform definition of death, the other issues that influence this area are the avoidable scams of organ donation (both live and deceased donor), and the expensive nature of transplant operations. We have to take up collective measures to correct these misconceptions.

This exercise is actually ongoing at various levels, as is exemplified by a noticeable work published in this volume of IJCCM. ${ }^{5}$ In a retrospective analysis of their brain death donation program and ensuing organ donation over the past two decades, the authors enlighten the readers with facts and factors influencing the positive changes that occurred at their center. Appreciable
Division of Critical Care, Continental Hospitals, Hyderabad, Telangana, India

Corresponding Author: Palepu BN Gopal, Division of Critical Care, Continental Hospitals, Hyderabad, Telangana, India, Phone: +91 9000361678, e-mail: palepu_gopal@hotmail.com

How to cite this article: Gopal PBN. Death, Brain Death, and Organ Donation: A Work in Progress. Indian J Crit Care Med 2020;24(9): 748-749.

Source of support: Nil

Conflict of interest: None

points of this work are the upward shift of age group of donors, increase in nontraumatic etiology of brain death, protocoldriven counseling strategy through a transplant coordinator, uniform donor management protocol and effective and clear communication. There are valuable practical lessons to be learnt from their work, which can be implemented as practice points at many other centers. The mantras for effective conversion of brain death to organ donation lies in the transparency of process and program, timing of counseling, technique of communication, touch with the family (empathy), assessing the tendency of donation of the family and deceased, and enlightening the donor family about targets, i.e., saving more than one recipients' life. Effectively done, these "Six T's" in most cases work productively and save several lives through a successful conversion of brain death into organ donation.

What else can be done to effectively resolve the confusion between two modes of death that are legally, but separately, recognized in many countries, including India? We can possibly emulate the US model and amend our registration of births and death act to include the brain death as a mode of death, paving way for greater acceptance and conversion to donation. Or does the definition of death itself need to be relooked into? Is the time ripe now to relook into these aspects?

Determining death and declaring the same are an empowered medical procedure following law of the land. We should all understand that when a medical professional declares death, following the procedure mandated by law, he or she is actually declaring the person to be "legally dead." Is this "legal death," either cardiac or brain death, equal to biological death? Are they two different entities? Surprisingly, we are not sure! Though George Bernard Shaw stated that "Only two things are certain in life, taxes and death," historically determination of definite death has always been a lively debate. As Henry K. Beecher stated "only a very bold man would attempt to define death". ${ }^{6}$ It is now widely accepted that dying is a process and death is a particular moment in that process. Death is an event in that dying process, a point when the person can be determined to have died. How to define and decide this specific moment? This question has been often directed at international regulatory and professional originations such as World Health Organization (WHO) and various transplant societies, among others.

(0) The Author(s). 2020 Open Access This article is distributed under the terms of the Creative Commons Attribution 4.0 International License (https://creativecommons. org/licenses/by-nc/4.0/), which permits unrestricted use, distribution, and non-commercial reproduction in any medium, provided you give appropriate credit to the original author(s) and the source, provide a link to the Creative Commons license, and indicate if changes were made. The Creative Commons Public Domain Dedication waiver (http://creativecommons.org/publicdomain/zero/1.0/) applies to the data made available in this article, unless otherwise stated. 
In May 2012, an invitational forum participated by 16 international organizations and 32 experts, which is sponsored by Health Canada and Canadian Blood Services in collaboration with the WHO, was held in Montreal, Canada. This was the first phase in the process of developing International Guidelines for Determination of Death. ${ }^{7}$ This forum fundamentally considered death as a biological event and arrived at a consensus of operational definition of human death. They identified three sequences in catastrophic brain injury (CBI) leading to neurological (brain) death: $\mathrm{N}-1$, which is continuing deterioration and progressive loss of brain function despite intervention; $\mathrm{N}-2$, which is cessation of brain function; and $\mathrm{N}-3$, which is cessation of brain function with no possibility to resume. They further identified three sequences in cardiorespiratory arrest (with and without CPR) leading to death: $\mathrm{C}-1$, which is cessation of circulation and breathing; $\mathrm{C}-2$, which is cessation of circulation and breathing with no possibility to resume spontaneously; and C-3, which is, cessation of circulation and breathing with no possibility to resume. They collectively argued that "Cessation of circulation and breathing with no possibility to resume spontaneously (C-2)" will render the brain ischemic and functionless and result in $\mathrm{N}-3$. This means that by the time one reaches $\mathrm{C}-3$ and declares a cardiac death, the brain is already dead! This led to the forum agreeing upon an operational definition of death as "Death is the permanent loss of capacity for consciousness and all brainstem functions. This may result from permanent cessation of circulation or catastrophic brain injury. In the context of death determination, 'permanent' refers to loss of function that cannot resume spontaneously and will not be restored through intervention." They also advocated avoiding terms such as "cardiac death" or "brain death" thereby implying death of an organ. Emphasis was placed on the cessation of neurological or circulatory function, and the centrality of brain function for determination of death. This is work in progress and will take a few more years to be recommended to be included in individual countries' laws.

At the end of the day, we need to undertake a multipronged approach to unify the legal definition of death with the aim of alleviating the doubt in the minds of the public that brain death is declared for organ donation. Even in the current form, efforts such as the ones made by Zirpe et al. have to be replicated in many other centers. Our policy makers of health need to closely track the international developments in these matters and dynamically make progressive changes in our laws. This will hopefully lead to a greater compliance in brain death declaration and organ donation.

\section{References}

1. The Transplantation of Human Organs and Tissues Act 1994. Available from: http://legislative.gov.in/sites/default/files/A1994-42.pdf.

2. National Organ Transplant Program. Director General of Health Services India. Available from: http://www.dghs.gov.in.

3. The Registration of Birth and Death Act, 1969 (Act No. 18 of 1969). Government of India; 31 May, 1969.

4. Uniform Determination of Death Act, 12 Uniform Laws Annotated (U.L.A.) 589 (West 1993 and West Supp. 1997.

5. Zirpe KG. Increase in cadaver organ donation rate at tertiary care hospital: 23 years of experience. Indian J Crit Care Med 2020; 24(9):804-808.

6. Kuiper MA, Kompanje EJO. Only a very bold man would attempt to define death. Intensive Care Med 2014;40(6):897-899. DOI: 10.1007/ s00134-014-3259-y.

7. Shemie SD, Hornby L, Baker A, Teitelbaum J, Torrance S, Young K, et al. International guideline development for the determination of death. Intensive Care Med 2014;40(6):788-797. DOI: 10.1007/s00134014-3242-7. 